\title{
Cross-Country Research on Earnings Quality: A Literature Review and Future Opportunities*
}

\author{
MASAHIRO ENOMOTO ${ }^{\dagger}$ \\ Research Institute for Economics and Business Administration, \\ KOBE UNIVERSITY
}

\begin{abstract}
Over the last two decades, a growing body of literature has investigated the factors influencing the differences in financial reporting, especially earnings quality, in an international setting. The purpose of this paper is to provide an overview of the crosscountry research that focuses on earnings quality and to offer suggestions for future topics in the field. In this study, I first discuss the relationship between earnings quality and the following institutional and cultural factors that have been examined in prior literature: legal tradition, investor protection (outside investor rights and legal enforcement), tax system, regulations, financial development, market competition, accounting standards (divergence from IAS), enforcement of accounting standards, culture, religiosity, and language. Second, the relationship between the improvement of earnings quality and International Financial Reporting Standards (IFRS) adoption is described. The results are mixed and suggest that a single set of accounting standards that are generally viewed as high quality does not always improve earnings quality. In addition, the relationship varies with the institutional and cultural factors of a country. It means that improvement through IFRS adoption would require the development of an institutional environment. Finally, as a prospect for future research, this paper discusses the extension from a single-country to cross-country study, the impact of IFRS adoption
\end{abstract}

\footnotetext{
* We gratefully acknowledge the useful comments and feedback from Keishi Fujiyama, Fumihiko Kimura, Kazunori Miwa, Kazuhisa Otogawa, Shota Otomasa, Masahiro Sakata, Akinobu Shuto, Shun-ichi Toyota, and Tomoyasu Yamaguchi. I would like to thank the financial support of JSPS KAKENHI Grant Number 17K04053 and 15K03763. Parts of this paper have been reconstructed based on Enomoto (2018). However, I have made significant additions to this paper, including analyzing the data, and updates to the referred studies, and providing future research areas

† Address: Research Institute for Economics and Business Administration, Kobe University, Rokkoudai 2-1, Nada, Kobe, 657-8501 Japan.Phone: 078-803-7031; Email: menomoto@rieb.kobe-u.ac.jp.
}

Received October 12, 2020; available online December 28, 2020

DOI: $10.11640 /$ tjar.10.2020.01

Copyright@2020 Research Institute for Economics and Business Administration - Kobe University. 
on the contracting role of accounting through the change in earnings quality, and earnings quality of non-listed firms in an international setting. These topics have become a more fruitful avenue of research with the recent increase in the availability of data.

Keywords: Cross-Country Research; Earnings Quality; IFRS

\section{Introduction}

For last two decades, a growing body of literature has studied the differences in financial reporting, especially earnings quality, in a cross-country research setting (e.g. Ball et al. 2000). Evidence of earnings quality in the individual country setting has been already provided by numerous studies. The institutional and cultural factors in a country should be associated with the relationship between stakeholders and management, corporate governance, and audits that are frequently focused on in the individual country setting. However, studies at an individual country level can ignore these factors because they have the same effects on all of the sample firms in that country. Therefore, a cross-country study is a suitable and useful setting to compare the effect of institutional and cultural factors on accounting information. This type of study provides an answer to questions as to what the crucial factors the differences in international accounting practices are. The purpose of this paper is to give an overview of cross-country research that analyzed earnings quality and provide suggestions for potential future research topics in this area. ${ }^{1}$

Country-level factors influencing earnings quality, outside-investors right, legal enforcement, financial development, tax system, market competition, accounting standards, and so forth have been tested in previous research. In most of the previous studies, common-law and strong investor protection countries have high earnings quality. Some studies show that financial development has a similar effect, but studies on cultural aspects report mixed results.

Controlling the divergence of accounting standards is a critical issue in the international setting. However, since firms listed on stock exchanges in EU countries are required to provide their annual report based on IFRS, these standards have prevailed around the world. IFRS provides many research opportunities to investigate the factors affecting earnings quality at country- and firmlevel. De George et al. (2016) report that research on IFRS published in academic accounting journals is increasing year by year especially since 2010. This corresponds to increased data availability since the enforcement of IFRS in EU security markets.

IFRS is generally viewed as high-quality accounting standards. The empirical research on the effect of IFRS adoption on earnings quality has failed to conclusively document the improvement of this quality (e.g. Barth et al. 2008; Ahmed et al. 2013b). Moreover, several studies report that the effect is conditional on the institutional environment in a country. Wysoki $(2011,322)$ states that accounting standards are just one of many institutional features in a country that influence firms' and managers' reporting incentives and therefore actual reporting and disclosure outcomes. In other words, adopting a single accounting standard that is viewed as high quality does not necessarily improve earnings quality. Rather, it may be important to establish institutional environments that enforce the accounting standards function appropriately.

The remainder of this paper is structured as follows. Section 2 summarizes the earnings quality

${ }^{1}$ Gordon et al. (2019) also provide several potential areas of future international accounting research. 
metrics in cross-country research. Section 3 presents the discussion on the relationship between earnings quality and institutional factors in the country, based on prior literature. For review, crosscountry studies are divided into three groups: (1) studies that explore institutional and cultural factors that determine earnings quality, (2) studies that examine whether IFRS adoption has improved earnings quality, and (3) studies that analyze the effect of institutional and cultural factors in the country on the relationship between earnings quality and IFRS adoption. In section 4, I discuss the future development of cross-country research. Section 5 concludes this paper.

\section{Earnings Quality Measures}

Numerous researchers have stated various definitions of earnings quality in their studies. Dechow et al. (2010, 10), who comprehensively survey earnings quality literature, define it as follows: Higher quality earnings provide more information about the features of a firm's financial performance that are relevant to a specific decision made by a specific decision-maker. Dechow et al. $(2010,346)$ classify the earnings quality measures in previous research into three categories as follows:

(a) Properties of earnings - earnings persistence, abnormal accruals and modeling the accrual process, earnings smoothness, asymmetric timeliness and timely loss recognition, and target beating,

(b) Investor responsiveness to earnings, and

(c) External indicators of earnings misstatements - indicators of firms subject to Securities and Exchange Commission (SEC) enforcements (Accounting and Auditing Enforcement Releases (AAERs)), Restatements, and internal control weaknesses.

In this survey, the range of earnings quality measure is limited to focus on managerial behaviors directly affecting accounting numbers. Investor responsiveness to earnings is excluded because it does not directly respond to managerial behaviors to alter accounting numbers. External indicators of earnings misstatements are not included because, due to the limited availability in an international database, the studies are scarce. Hence, this paper concentrates on (a) properties of earnings that can be interpreted as direct managerial intervention in accounting numbers. A certain percentage of studies reviewed in herein examine earnings management in an international setting. Earnings management occurs when managers use judgment in financial reporting and in structuring transactions to alter financial reports either to mislead stakeholders about the underlying economic performance of the company or to influence contractual outcomes that depend on reported accounting numbers (Healy and Wahlen 1999, 368). According to the definition, earnings management leads to a distortion of the accounting numbers. This study, therefore, assumes that earnings management decreases earnings quality as posited in most previous papers. $^{2}$

Earnings management research shows that it is closely associated with the transparency and information asymmetry that comprise earnings quality. Thus, earnings management represents a crucial factor affecting earnings quality (Dechow et al. 2010). Real earnings management and

${ }^{2}$ Holthausen (1990) defines earnings management (accounting choice) from the viewpoints of efficient contracting, and information perspectives, in addition to opportunistic behavior. His definition means that a part of earnings management stems from non-opportunistic motivation and may not deteriorate earnings quality. 
accrual-based earnings management are key elements of earnings management. In addition to the aforementioned properties of earnings, it is an important proxy of earnings quality. ${ }^{3}$ Therefore, this study includes the real earnings management literature at an international level as part of the survey, although not that reviewed in Dechow et al. (2010).

\section{Cross-Country Research on Earnings Quality}

\subsection{The Relationship between Earnings Quality and Institutional and Cultural Factors in a Country 3.1.1. Legal Tradition and Investor Protection}

La Porta et al. $(1997 ; 1998)$ are novel studies that have influenced cross-country research in the field of accounting. Their studies document that common-low countries have stronger investor protection and more developed capital markets, while code-law countries have relatively weak investor protection and their capital markets are less developed. Since La Porta et al. (1997; 1998), most cross-country earnings quality research has employed their measures of legal tradition, outside investor rights, and legal enforcement. ${ }^{4}$

Ball et al. (2000) draw inferences about the relationship between legal tradition and earnings quality. In their arguments, the corporate governance system in common-law and code-law countries is dominated by the shareholder and stakeholder, respectively. On one hand, the shareholder corporate governance system in common-law countries tends to use public disclosure to mitigate information asymmetry and have timely recognition of economic losses. On the other hand, the stakeholder corporate governance system in code-law countries is likely to rely on private communication for the mitigation of information asymmetry and the payout for stakeholders would therefore be directly related to accounting income. Accounting in code-law countries has a tendency towards less timely recognition of economic losses and income smoothing for payout stabilization.

Based on a sample of 40,359 firm-years from four common-law countries (Australia, Canada, the U.K., and the U.S.) and three code-law countries (France, Germany, and Japan) between 1985 and 1995, they document that accounting income in common-law countries incorporates economic losses in a more timely manner than that in code-law countries. However, Ball et al. (2003) provide evidence that the four common-law countries with accounting standards generally viewed as highquality in East South Asia (Hong Kong, Malaysia, Thailand, and Singapore) show less timeliness and conservative accounting income than code-law countries (France, Germany, and Japan). Their evidence suggests that earnings quality in a country is necessarily not related to the legal tradition and suggests that researchers should note the managerial incentive to financial reporting.

Turning to the effect of investor protection on earnings quality, Leuz et al. (2003) provide a pioneering study indicating the relationship between investor protection and earnings management. They employ outside investor rights and legal enforcement as investor protection measures. Outside investor rights represent the extent of investor protection by law and is measured by whether or not five of the outside investor rights to counter the directors exist. ${ }^{5}$ Leuz et al. (2003) argue that insiders (the controlling shareholder and the managers in possible collusion with it) manage

${ }^{3}$ Researchers mainly calculate real earnings management measure using the model of Roychowdhury (2006).

${ }^{4}$ Legal family is also considered in many studies.

${ }^{5}$ Djankov et al. (2008) propose a new legal protection measure of outsider against expropriation by corporate insiders' self-dealing (anti-self-dealing index). Spamann (2010) presents a revised measure of the index of La Porta et al. (1997, 1998). 
earnings to conceal an unfavorable earnings decrease caused the expropriation of the minority shareholders' wealth. However, if it is difficult for managers to expropriate from minority shareholders due to strong investor protection, the incentives for implementing earnings management ought to be curbed. Therefore, they claim that countries with a higher the level of investor protection have higher earnings quality.

Based on a sample of 70,955 firm-years in 31 countries from 1992 through 2001, Leuz et al. (2003) find that firms in countries with stronger investor protection limit earnings management, which improves earnings quality. This means that legal protection tends to mitigate the conflict between minority shareholder and insider. Moreover, they state that weak legal protection may cause financial reporting to deteriorate and that it undermines the development of so-called "arm's length" financial markets.

In accordance with Ball et al. (2000) and Leuz et al. (2003), many studies have been conducted on the association of legal tradition and investor protection with earnings quality. Using data from 22 countries between 1990 and 1999, Haw et al. (2004) report that earnings quality is heightened in a country with common-law, an efficient judicial system, and high tax compliance. Using 86,927 firm-years from 1992 to 2001 across 38 countries, Bushman and Piotroski (2006) show that firms in common-law countries have greater timely accounting recognition of economic losses (TLR) compared to those in code-law countries. Even after controlling for the legal tradition, firms in countries with stronger investor protection and judicial systems show similar results. ${ }^{6}$

Leuz et al. (2003) predominantly focus on accounting accruals as a proxy for earnings management. Accounting accruals are mainly used as accrual-based earnings management. As previously mentioned, real earnings management is also one of the primary managerial discretionary behaviors. Previous research provides evidence that the two discretionary behaviors tend to have a substitution relationship (e.g. Ewert and Wagenhofer 2005; Cohen et al. 2008). Enomoto et al. (2015) investigate whether substitution relationships are observed under strong investor protection. Based on a sample of 222,513 firm-years from 38 countries from 1991 through 2010, they document that managers in countries with stronger investor protection tend to engage in real earnings management in order to compensate for a reduction in accrual-based earnings management. High analyst coverage, which is a proxy for capital market forces, limits real earnings management. Similarly, Francis et al. (2016), using a sample of 245,180 firm-years in 38 countries from 1994 to 2009, demonstrate that managers in countries with stronger investor protection are likely to curb accrual-based earnings management resulting in an increase in real earnings management. In other words, they show a substitutional relationship between the two discretional behaviors.

Similar to Leuz et al. (2003), most research provides evidence of higher earnings quality in countries with stronger investor protection. Boonlert-U-Thai et al. (2006) examine a sample of 57,610 firm-years in 31 countries from 1996 to 2002 to explore the relationship between investor protection and earnings quality, such as accrual quality, earnings persistence, earnings predictability,

${ }^{6}$ Bushman and Piotroski (2006) provide the following arguments regarding the relationship between legal system and conservatism. In countries where the quality of legal system is higher, accounting figures play an important role in formal contracts, where enforceable contracts are required and verifiable accounting figures are demanded by contracting bodies. Moreover, the higher the quality of the judicial system, the greater the benefits gained from litigation. Overstating economic performance will raise potential litigation costs. Therefore, firms in countries with a higher quality legal system have a greater degree of conservatism. 
and income smoothing. In contrast to Leuz et al. (2003), they report that countries with stronger investor protection show lower earnings quality, lower earnings predictability, and less smoothed earnings. The results of earnings persistence are unclear. They also draw inferences that, due to the extensive use of accounting information for contracting in developed countries, managers tend to obtain gains through earnings management. ${ }^{7}$

Although the aforementioned studies are based on non-financial firms and exclude financial firms as their sample, Shen and Chih (2005) focus on banks. Based on a sample of banks from 1993 to 1999 , they report that in two-thirds of 48 countries banks engage in earnings management to avoid loss and/or decrease in earnings. They find that the strength of investor protection and transparency of accounting disclosure is significantly negatively associated with the tendency of loss avoidance, whereas legal enforcement is positively related to avoidance of decrease in earnings. These results are inconsistent with Leuz et al. (2003), but they do not provide a clear explanation for the conflict.

Differing from Shen and Chih (2005), Kanagaretnam et al. (2010) study a sample of 6,072 bank-years in 29 countries from 1993 to 2006 in order to compare the relationship between audit quality and earnings management in an international setting. Firms with high-quality auditing and in countries with strong legal enforcement have a less tendency towards loss and decrease in earnings avoidance. In addition, Fonseca and Gonzalez (2008) and Kanagaretnam et al. (2014) also have similar results to Kanagaretnam et al. (2010).

\subsubsection{Culture}

Cultural effects constitute one of the main avenues of earnings quality research in an international setting. Most research use the power distance, individualism, masculinity, uncertainty avoidance, and long-term orientation as cultural factors in Hofstede (1980, 2001). ${ }^{8}$ Gray (1998) states that individualism and uncertainty avoidance are more closely related to accounting. Hope (2003) finds that individualism and uncertainty avoidance are associated with the level of accounting disclosure.

There are two competing arguments in previous studies on how culture influences earnings quality at a country level. ${ }^{9}$ When narrowed down to individualism and uncertainty avoidance as pointed out by Gray (1998), Hope (2003), Guan et al. (2005), Han et al. (2010), Kanagaretnam et al. (2011), and Pacheco Paredes and Wheatley (2017), there is evidence that greater individualism and lower uncertainty avoidance lead to a decrease in earnings quality. For example, Han et al. (2010) argue that countries with greater individualism have more flexible accounting standards from the viewpoint of self-governance and measurement flexibility. Moreover, the accounting profession in countries with a higher level of individualism is assumed to report the most optimistic figures as far as is permitted by the accounting standards. Accounting regulation in countries with

7 They claim that since the earnings management measures in Leuz et al. (2003) are developed to test U.S. firms, the measures may not be suitable for cross-country research.

8 Several studies examine the relationship between earnings quality and Gray's (1988) accounting values (professionalism, uniformity, conservatism, and secrecy) based on national cultural dimensions as in Hofstede (1980). For example, Doupnik (2013), Salter et al. (2013), and Wijayana and Gray (2019) employ the conservatism dimension.

9 These mixed findings appear to partly reflect the differences in how to aggregate the earning quality data. Guan et al. (2005), Han et al. (2010), Kanagaretnam et al. (2011), and Pacheco Paredes and Wheatley (2017) calculate earnings quality measures by firm-year, while Doupnik (2008) and Callen et al. (2011) aggregate them by country. It could be that the difference in empirical results depends on researcher's setting. 
higher uncertainty avoidance imposes many rules and its approach ought to be conservative. As such, Han et al. (2010) state that higher uncertainty avoidance tends to lead to less earnings management.

Doupnik (2008) and Callen et al. (2011) present opposite results. They presume that the higher the level of uncertainty avoidance, the more earnings quality deteriorates due to the implementation of earnings management in order to avoid violations of debt covenant and missing the earnings forecasts of analysts. In contrast, if there is a strong collectivist culture, employees hope that they will be treated like a member of the family in their organization and that their interests will be protected. Income smoothing then plays an important role in goal achievement. Doupnik (2008) finds that countries with weaker individualism (i.e. strong collectivism) tend to smooth income and, thereby, protect the collective interests. ${ }^{10,11}$

\subsubsection{Financial Development and Others}

Accounting information plays an important role in financing from financial institutions and securities markets. The financial development of a country has a relationship with accounting information, including earnings quality. However, there are not enough studies to test the relationship between them. Degeorge et al. (2013) assume that in countries with high financial development, more accounting information is provided, investors demand more accounting information, analysts are better qualified, and as firms are followed by more analysts they have the incentive to be monitored. ${ }^{12}$ Using the data of 65,799 firm-years from 21 countries between 1994 and 2002, their results show that in countries with high financial development, the higher the analyst coverage, the lower the level of earnings management and, therefore, the higher the earnings quality. However, these results are not observed in countries with lower financial development. The results suggest the complementary effect of analyst coverage on financial development.

Enomoto et al. (2018) examine the relationship between financial development and earnings management in a sample of 56,830 firm-years from 37 countries from 2009 to $2012 .{ }^{13}$ They document that managers in countries with higher financial development tend to avoid both accrualbased and real earnings management (i.e., earnings quality is high), indicating the possibility that financial development effectively disciplines managerial discretional behaviors.

In addition to the aforementioned literature, Braam et al. (2015) show the effect of political connection and freedom of the press on earnings quality, using a sample of 5,493 firms in 30 countries. They provide evidence that politically connected firms tend to employ real earnings management in substitution for accrual-based earnings management more than non-politically connected firms. Yung and Root (2019), based on a sample of 79,230 firm-years from 18 countries between 2001 and 2014, find that higher policy uncertainty leads to an increase in earnings management.

${ }^{10}$ Ding et al. (2005) find that culture is a more important explanatory factor for the difference between local GAAP and IAS than legal origin. Specifically, when culture is incorporated into the regression of divergence on institutional factors, they do not find a relationship between divergence and legal origin.

${ }^{11}$ In addition to the aforementioned literature, Kanagaretnam et al. (2015) show the effect of religiosity on earnings quality. Kim et al. (2017) provide evidence that earnings quality is affected by language.

12 For example, financial development is measured by bank credit as the claims of the banking sector on the private sector divided by GDP and the value of listed shares as a share of GDP (Beck and Levine 2002).

13 They use the average score of seven indices reported in the World Economic Forum (2012) as a measure of financial development. 
3.1.4. Brief Summary of the Relationship between Institutional Factors and Earnings Quality.

Results of previous literature suggest that earnings quality is influenced not only by accounting standards, but also by the institutional and cultural factors in a country. Specifically, it is likely that higher earnings quality is observed in countries that have common-law, stronger outside investor rights and legal enforcement, and higher financial development.

In cross-country research on earnings quality, there is a limitation in that it does not consider differences in the accounting standards of each country. Ding et al. (2007) focus on divergence as the extent to which accounting rules are different from local accounting standards and IAS for the same accounting issue. They find a negative relationship between earnings quality and divergence. The results suggest that differences in accounting standards themselves are related to earnings quality and that controlling the difference is crucial for cross-country study.

Next, most cross-country studies do not identify the mechanism of how institutional factors at country level influence managerial accounting behavior. Wysocki $(2011,316)$ pointed out that the limitation of the broad "code" vs. "common" law approach is that it is unclear which institutions from "common law" regimes are the drivers and facilitators of (a) arm's length contracting and (b) determinants of timely loss recognition (TLR). In addition, the outside investor rights index is calculated based on whether or not these rights are enacted. It is also unclear whether the rights actually function as expected, nor whether it is a comprehensive proxy covering the entire scope of investor protection. Obinata (2016) also casts doubt on whether the five law provisions selected in La Porta et al. (1998) are sufficient as a proxy for the protection of shareholders' and creditors' rights, or whether there are no other mechanisms to protect them even if it is not included in the law.

As with the investor protection measures, the ambiguous relationship between legal enforcement and earnings quality has been pointed out (e.g. De George et al. 2016). Brown et al. (2014) mitigate the concerns by developing measures for accounting standard enforcement. Their measures allow us to elaborate the relationship between enforcement and earnings quality.

The effect of cultural factors on accounting information remains dubious. When managerial behaviors through cultural factors decrease earnings quality, it is not clear why these behaviors occur in spite of the predictable economic consequences of managerial behavior. Moreover, one of the important concerns is that the relationship between culture and earnings quality can be interpreted twofold. As previously described, Doupnik (2008) and Han et al. (2010) present conflicting prediction and results. Since culture ought to influence the institutional environment at a countrylevel as well as influence managers at a firm level, it would be difficult to specify the relationship between them correctly. ${ }^{14}$

As accounting systems are mutually dependent on other systems (legal system, corporate governance mechanism, investor protection, and disclosure, etc.), "chicken and egg" problems need to be highlighted (Wysocki 2011, 312). To solve the problems requires complicated model specifications, but may provide the opportunity for interesting future research.

\subsection{The Relationship between Earnings Quality and IFRS Adoption}

This subsection aims to review empirical studies on how IFRS adoption effects earnings quality and which institutional factors in the country promote or weaken the effects.

${ }^{14}$ Griffin et al. (2017) analyze the direct influence of culture on institutions in a country, using multi-level analysis. 
The following three key features of IFRS appeared in the literature on earnings quality.

(1) Principle-based standards

IFRS develops basic principles and does not set detailed rules. In the accounting process, it is necessary to make judgments according to individual circumstances and economic events.

(2) Fair value measurement

IFRS use the asset / liability approach. Therefore, there are many cases where a manager estimates fair value.

(3) Restriction on accounting choice

IFRS limit the options of accounting choice in order to eliminate earnings management by discretionary accounting choice as far as possible.

There are conflicting but plausible arguments regarding whether or not the adoption of IFRS improves earnings quality based on the aforementioned characteristics (Ashbaugh and Pincus 2001; Barth et al. 2008; Ahmed et al. 2013b). On one hand, the increase in the opportunity for fair value measurement in order to disclose the present value of assets and liabilities could improve earnings quality and provide useful information for investor's decision-making. The reduction of alternative accounting choices would increase earnings quality through the limitation of managerial discretionary behaviors.

On the other hand, insufficient implementation guidance due to principle-based accounting standards may increase managerial behaviors to manage earnings. More opportunities for fair value measurement may increase managers' flexibility with regard to calculation of values. The elimination of alternative accounting choices would prevent the disclosure of the true underlying economics of a business. These two are often described in cross-country research on IFRS.

\subsubsection{Effect of IFRS Adoption on Earnings Quality}

Focusing on the effect of voluntary IFRS adoption on earnings quality, Barth et al. (2008) compare the earnings quality of firms that voluntarily adopted IFRS with that of non-adoption firms based on a sample of 1,896 firm-years in 21 countries from 1994 through 2003. They find that voluntary adoption firms show higher earnings quality (less earnings management, income smoothing, and loss avoidance) and value-relevance. They conclude that IAS adoption leads to the improvement of earnings quality.

In contrast to Barth et al. (2008), Ahmed et al. (2013b) investigate the effect of mandatory IFRS adoption. Using a sample of 16,310 firm-years from 25 countries from 2002 through 2004 (pre-IFRS) and 2002 through 2004 (post-IFRS), they find that mandatory adoption leads to greater income smoothing, larger accounting accruals, and lower timely loss recognition, which means a deterioration in earnings quality. They also find that earnings management to meet or beat earnings benchmarks increase after IFRS adoption. However, based on a sample of 20,278 firmyears from 15 countries from 1994 through 2009, Capkun et al. (2016) find that mandatory adopters exhibit higher levels of earnings quality after IFRS adoption. Chen et al. (2010) document that mandatory adopters reduce earnings management, improve accounting accrual quality, and lower earnings management to meet or beat earnings benchmark following IFRS adoption. Their findings were based on a sample of 21,707 firm-years from EU 15 countries from 2000 through 
2007..$^{15}$

Using a sample based on 1,574 in European countries between 2001 and 2008, Zeghal et al. (2012) find that mandatory adopters show less earnings management, higher quality of accounting accruals, less loss avoidance (the improvement of earnings quality). ${ }^{16}$ Houqe et al. (2016), using a sample of 24,034 firm-years in $16 \mathrm{EU}$ countries, report similar results. However, based on a sample of 15,206 firm-years from EU 22 countries between 2000 and 2010, Doukakis (2014) finds that IFRS mandatory adoption does not have a significant effect on real earnings management nor accrual-based earnings management.

The aforementioned results are mixed as to whether or not mandatory adoption of IFRS improves earnings quality. In the next section, we will discuss how the institutional factors of each country intervene in the change in earnings quality after IFRS adoption.

\subsubsection{Effect of Institutional Factors on the Relationship between Earnings Quality and IFRS Adoption}

This subsection discusses whether the evidence in subsection 3.2.1. is conditional on the institutional factor of each country. In subsection 3.1., the evidence that earning quality is influenced by institutional and cultural factors in the country was reviewed. The effect of IFRS adoption and earnings quality may depend on institutional factor such as investor protection.

Aussenegg et al. (2008) use the data of 18,896 firm-years from 17 EU countries from 1995 to 2005 and consider the legal tradition to test the effects of voluntary IAS adoption. They report that voluntary adopters improve earnings quality, but it is conditional on legal origin, in particular German and French legal origin. ${ }^{17}$ Countries with legal systems of English or Scandinavian origin do not significantly benefit from IAS adoption. Zehal et al. (2012) divide their sample based on the difference between local GAAP and IAS, the adopters in countries where standards are most different from IFRS improve earnings quality. Using a sample of 128,292 firm-years from 31 countries from 2000 through 2009, Cai et al. (2014) observe that firms adopting IFRS experience less earnings management after adoption. However, their results only hold for firms in countries with a high quality of legal enforcement and a relatively small difference between local GAAP and IFRS. From the sample data of 53,861 firm-years from 14 countries between 1997 and 2015, Oz and Yelkenci (2018) focus on Morgan Stanley Capital International (MSCI) firms in IFRS countries. They show that IFRS constrains accrual earnings management in code law origin countries, but does not under common law. Further, they report the negative joint effect of IFRS and legal enforcement on real earnings management in common law countries. ${ }^{18}$

Houqe et al. (2012) focus on the effect of investor protection on the improvement of earnings quality after IFRS adoption. ${ }^{19}$ They report that positive effects on earnings quality are confined to firms in countries with stronger investor protection. Houqe et al. (2016) find that the improvement of earnings quality of mandatory adopters is more pronounced in countries with a stronger culture

15 However, they show stronger income smoothing and less timely recognition of economic losses.

16 Timeliness, conservatism, and value relevance are not improved.

17 Ding et al. (2007) report that the accounting standards in the countries with the German and French law families are large deviations from IAS and that the improvement of earnings quality is observed in those countries, consistent with Zeghal et al (2012) and Cai et al. (2014).

18 They show that IFRS itself does not reduce real earnings management.

19 The enforcement of the accounting standard in Houqe et al. (2012) is provided by the World Economic Forum (2008). 
of secrecy.

André et al. (2015) and Bonetti et al. (2016) use the enforcement measures of accounting standards in the country, which are developed in Brown et al. (2014). André et al. (2015) find that firms delay timely loss recognition after IFRS adoption. Based on a sample of 13,711 firm-years from EU 16 countries from 2000 through 2010, André et al. (2015) illustrate an inadequate impairment testing as one of the plausible explanations, which means that managers delay the recognition of bad economic news and thereby decrease conditional conservatism. Meanwhile, the decrease is mitigated by strong accounting standards enforcement. They interpret the findings that IFRS cannot improve earnings quality without appropriate enforcement because it increases the flexibility of accounting standards. Bonetti et al. (2016) explain the difference in the improvement of earnings quality after IFRS adoption as due to the enforceability of accounting standards. They find that improvement of earnings quality after IFRS adoption is promoted in strong legal systems and accounting standards, using data of 28,824 firm-years from 14 EU countries between 2002 and 2008. They also find that strong corporate governance increases earnings quality, even if the country has a relatively weak institutional environment.

In contrast, Ahmed et al. (2013b) show that the decline in earnings quality is driven by countries with strong legal enforcement. Doukakis (2014) reports that the mandatory application of IFRS has an insignificant impact on both accrual-based and real earnings management even though the legal enforcement is controlled. Using a sample of 53,853 firm-years from 37 countries between 2000 and 2008, Ipino and Parbonetti (2017) assert that the substitution between accrualbased and real earnings management is strengthened when local accounting standards diverge from IFRS and financial statements are audited by Big-N audit firms.

\subsubsection{Brief Summery}

The firms in countries that have adopted IFRS prepare their financial statements in line with common accounting standards. This mitigates the underlying problem in cross-country studies, which is the difference in earnings quality caused by divergence between accounting standards.

Earnings quality tends to be improved after voluntary adoption of IFRS, whereas it is inconclusive after mandatory adoption. As Capkun et al. (2016) point out, this result is consistent in that voluntary adopters change to IFRS with incentives to improve earnings quality. Based on a sample of German firms, Christensen et al. (2015) document a significant improvement of earnings quality for voluntary adopters, but not for mandatory adopters. Their findings are consistent with those of Barth et al. (2008) and Ahmed et al. (2013b).

Several studies have found that earnings quality after IFRS adoption is conditional on strong investor protection and/or large differences between IFRS and local GAAP. In other words, earnings quality does not necessarily improve even when adopted accounting standards are generally viewed as high quality. The improvement of earnings quality depends on the institutional factors in each country. The difference in improvement of earnings quality also means that the response of managers to IFRS varies according to differing institutional factors in each country. In addition, one possible explanation for mixed results is the difference in research design such as the time-periods and countries used for a sample, earnings management measures, and so forth. This may be an empirical issue.

In an analysis of the transition from local GAAP to IFRS, it is necessary to control change in institutional factors as well as accounting standards. Although legal enforcement is recognized as a crucial factor in the improvement of earnings quality and its changes differ across countries, it is 
not controlled in most studies (Christensen et al. 2013). For example, Ishidro et al. (2020) focus on the change in country attributes under the relationship between earnings quality and mandatory IFRS adoption. They find that the effect of IFRS adoption on earnings quality disappears when controlling for change.

Ahmed et al. (2013a) conduct a meta-analysis of 57 IFRS adoption studies to investigate whether adoption has an effect on earnings transparency, which is measured by discretionary accruals and capital market effects. Their findings show that neither voluntary nor mandatory adoption of IFRS reduces discretionary accruals.

\section{Summery and Future Research}

\subsection{Interaction within an Individual and Cross-Country Setting}

The research overviewed in section 3.1 reports that the following country level factors affect earnings quality, legal origin, investor protection (outsider investor right and legal enforcement), tax system, regulations, political system, culture, language, religiosity, the development of the security market and banking system (financial development), and accounting standards enforcement.

Numerous studies in an individual country setting have also examined the various factors that influence earnings quality. We can explain the discussion in section 3.1 from the viewpoint of an individual country setting. It can be said that cross-country research investigate whether the evidence provided by an individual country sample is universal or varies according to the level of institutional and cultural factors. For example, the U.S., which is frequently used as a sample in single-country studies, is generally viewed as a country with enhanced investor protection and strong corporate governance. Nevertheless, it still leaves many unanswered questions about whether the evidence from the U.S. is true in the case of other countries with the different institutional and cultural environments. Moreover, institutional and cultural factors at the country level may be a substitute for the factors affecting the earnings quality at an individual firm level (see Bonetti et al. 2016 described later).

For example, given that previous research finds better earnings quality in firms with Big-N auditors (e.g. Becker et al. 1998 and Francis et al. 1999). Francis and Wang (2008) extend their studies to cross-country research and report that the evidence in the U.S. tends to be true only in countries with higher investor protection. This means that the effect of audits conducted by Big-N auditors on earnings quality weakens in countries with lower investor protection. Gopalan and Jayaraman (2012) provide the evidence for income smoothing in firms controlled by insiders only in countries with weak investor protection. Degoerge et al. (2013) find that analyst coverage improves earnings quality, but it is limited to countries with a high level of financial development. Haw et al. (2015) show the positive relationship between industrial competitiveness and conservatism exists only in countries with high-quality legal systems. Bonetti et al. (2016) find earnings management after IFRS adoption is less noticeable in countries with strong accounting enforcement. Moreover, for firms with a higher corporate governance score, IFRS adoption decreases earnings management regardless of the strength of accounting standards enforcement, suggesting that better firm-level corporate governance systems could be a substitute for institutional factors at the country-level.

As described in Section 2, many attributes of earnings quality are utilized in the previous literature. For example, discretionary accruals, accounting quality of the model used by Dechow and 
Dichev (2002), income smoothing, timely loss recognition, and benchmark-beating. Since each measure of earnings quality has its own attribute, it is possible to select quality measures that fit the research question.

The influence of investor attributes (foreigners, institutions, etc.) on earnings quality has been examined by studies that extend an individual country setting to an international one. It is recognized from conflicting results in previous studies at an individual country level that foreign institutional investors lessen earnings quality by inducing myopic management behavior or improve earnings quality by monitoring managers.

Foreign investors can be investigated from multiple viewpoints at an international level. Aggarwal et al. (2005) show the relationship between investment from institutional investors in the U.S. and country- and firm-level quality of accounting. The redesign of their investigation from the viewpoints of cross-country study could provide interesting outcomes. For example, the institutional environment in foreign investors' home and investee's countries, the geographical, cultural, and legal distance between the investor and investee, and institutional or individual investors can be examined simultaneously. Kim et al. (2016), Beuselinck et al. (2017), Lel (2018), and Tsang et al. (2019) shed the light on these aspects in an international setting. Dou et al. (2016) examine the effects of individual investors on earnings quality instead of total foreign investor ownership. ${ }^{20}$ An extension of Dou et al. (2016), Kim et al. (2016), and Beuselinck et al. (2017), Lel (2018), and Tsang et al. (2019) may be an interesting avenue for future research. The detailed firmlevel corporate governance data allows us to carry out this potential research. It is no exaggeration to say that the future of cross-country research depends on an availability of firm-level data, such as corporate governance, shareholders, and board members. (See subsection 4.4.).

\subsection{Earnings Quality and its Effect on Accounting Functions}

Brüggemann et al. (2013) summarize the economic consequences of IFRS adoption in the EU. They divide the consequences into three parts: financial reporting, capital market, and macroeconomic. They conclude that IFRS objectives result in favorable capital market and macroeconomic effects.

As a capital market effect, Daske et al. $(2008,2013)$ find that IAS/IFRS adoption increases stock liquidity and lowers the cost of capital. Yip and Young (2012) report an increase in comparability after IFRS adoption. $\mathrm{Li}$ (2010) reports a decrease in the cost of capital in countries with strong legal enforcement.

Gordon et al. (2012) provide the macroeconomic evidence to suggest that direct investment increases for developing countries adopting IFRS. Chen et al. (2011) also report similar results in OECD countries, especially in countries with greater divergence between IFRS and local GAAP before the adoption of IFRS.

The effects of IFRS on financial reporting, however, are mixed (e.g. Barth et al. 2008, Ahmed et al. 2013b, and Doukakis 2014). Moreover, institutional factors such as investor protection and accounting standards enforcement influence the change in earnings quality after IFRS adoption, but these results are also mixed. Two plausible explanations for these inconclusive results described in Brüggemann et al. $(2013,2,19)$ are that previous literature applies aggregate measures that capture only a subset of potential changes in financial reporting and that the financial statement

${ }^{20}$ Dou et al. (2016) employ an individual country setting (U.S.), not cross-country. 
users are also interested in information beyond such aggregate numbers.

The primary area of economic consequences regarding IFRS adoption is research on the change in the contracting role of accounting such as accounting based debt covenants. Several studies have addressed the issue of the contracting role of IFRS on the type of debt financing (public versus private), credit relevance, cost of debt, and so forth. However, in previous literature, the effect of IFRS adoption on debt contracting is conflicting. For example, Kim et al. (2011) report a decrease in the cost of capital for voluntary adopters, whereas Chen et al. (2015) show in increase in it for mandatory adopters. Although some studies assume the improvement of financial reporting quality after IFRS adoption and the mitigation of information asymmetry, it does not seem that the improvement always occurs in the countries mentioned in the sample data.

As in the case of debt contracts, there is scant evidence for the economic consequences of IFRS adoption on compensation contracts. Ozkan et al. (2012) report a significant increase in accounting based pay-performance sensitivity and relative performance evaluation. ${ }^{21}$ The latter results only hold in countries with a large difference between IFRS and local GAAP, suggesting that IFRS increases the comparability of accounting numbers after IFRS adoption.

Given that the improvement in earnings quality after IFRS adoption is subject to institutional factors at the country-level, the change in a contracting role due to IFRS adoption could be influenced by institutional factors. Future research should attempt to explore the mechanism of how institutional factors affect the contracting role through the change in earnings quality.

In previous literature, the economic consequences of IFRS adoption are unclear. This is because the adoption of IFRS adoption may promote the timely recognition of economic losses through the expanding measurement of fair value and would also make accounting figures informative. However, adoption may increase managerial discretional behaviors and decrease the verifiability of accounting information through widely used fair value measurement. Moreover, managers may engage in earnings management in order to communicate private information, whereby an increase in earnings management could have a positive effect on earnings quality. Such features of earnings management could make the economic consequence of IFRS adoption complicated. However, I believe that future research will shed more light on whether financial reporting after IFRS adoption improves usefulness in contracts at an international level. It is of interest for researchers to incorporate the communication with stakeholders through private information, including earnings management into research design.

\subsection{Cross-Country Research on Non-Listed Firms}

This paper has discussed earnings quality at an international level, focusing on listed firms. However, non-listed firms account for the majority of firms. Hope and Vyas $(2017,506)$ state that whereas there are numerous studies on publicly listed companies, the empirical evidence on private firms is rather limited. Burgstahler et al. (2006) is a novel study reporting the difference in earnings quality between listed and non-listed firms in an international setting. They find better earnings quality for listed firms than for non-listed firms, which is caused by institutional factors such as

${ }^{21}$ In addition to Ozkan et al. (2012), Voulgaris et al. (2014) investigate the relationship between IFRS adoption and compensation contracts based on U.K firms. Chen and Tang (2017) examine Hong Kong firms. 
book-tax alignment, outside investor protection, and capital market structure. ${ }^{22}$

Non-listed firms are not necessarily small in size. For example, some non-listed firms like Bosch and IKEA are well-known as large scale firms and play an important role in the economy. Japan has relatively higher percentages of large firms that are listed compared to other countries. Miyajima (2017) reports that the percentage of listed companies in the top 1,000 sales companies was 54.2\% in 2013 while Franks et al. (2012) document that, in 1996 the percentage of those in the U.K. was $27.4 \%$, Germany $14.5 \%$, France $13.6 \%$, and Italy $8.4 \%$. It is worthwhile considering non-listed firms for an empirical study on earnings quality from the viewpoint of economic importance. Hope et al. (2013) use sample firms with total assets of more than one million U.S. dollars, but exclude observations with negative sales.

In order to discuss cross-country non-listed firm research, the availability of non-listed firm data at an international level is presented. Table 1 summarizes the available number of listed and non-listed firms in the 51 countries around the world in 2015. Panel A in Table 1 shows the results of 49 countries included in La Porta et al. (1997) and Panel B adds China and Russia. Firm data is derived from Orbis (Bureau van Dijk) under the condition that in 2015 total assets and sales are equal and more than 100,000 U.S. dollars. ${ }^{23}$ The second, third, and fourth columns from the left in Table 1 display the available number of firms. In the fifth to eighth columns in Table 1, the available number of return on assets $(R O A)$ and Accruals that are frequently used in earnings quality studies are presented. $R O A$ is calculated as net income divided by average total assets. Accruals is calculated in the following way and divided by total assets at the previous fiscal year end.

$$
\begin{aligned}
\text { Accruals }= & \Delta(\text { Current assets }- \text { Cash }- \text { Short-term investment })-\Delta(\text { Current liability } \\
& - \text { Short-term debt })- \text { Depreciation }
\end{aligned}
$$

Accruals is calculated when both current assets and liabilities have no-zero value. Next, earnings quality measure used in Hope et al. (2013) is calculated, which compares the earnings quality of listed firms with that of non-listed firms in the U.S. The measure (Earnings Quality) take the natural logarithm of the absolute value of accruals divided by $C F O$ and multiple negative one so that higher values indicate higher earnings quality $(=\ln (\mathrm{abs}[$ Accruals $/ C F O]) \times(-1))$. The first column from the right shows the percentage of listed-firms among the top 100 sales firms in each country. The number of listed firms whose financial statements are prepared under IFRS is also presented.

Panel A of Table 1 shows that 2,651,763 firms are available in 2015 in 49 countries. Even with calculable of Accruals, available data is 1,660,266 firms. This is a sufficient sample size for empirical analysis on earnings quality. However, the data availability of non-listed firms is centered on European countries. This result depends on the economic scale and filing regulations in each country. Gassen's $(2017,549)$ Table 5 shows the availability of financial statements of non-listed firms in 24 countries. He reports that the financial statements of non-listed firms are available

22 Bonacchi et al. (2019) also find that public firms have better earnings quality than private firms. However, when dividing the private firms into standalone (single entity) and business groups and comparing public firms with the business groups, they find conflicting results.

${ }^{23}$ For example, Gassen and Fulbier (2015), who focus on the non-listed firm at an international level, collect their sample firms with total assets over 100,000 U.S. dollars. Hope et al. (2017) gather the U.S. firms with total assets over 1,000,000 U.S. dollars and non-negative sales as their sample. 


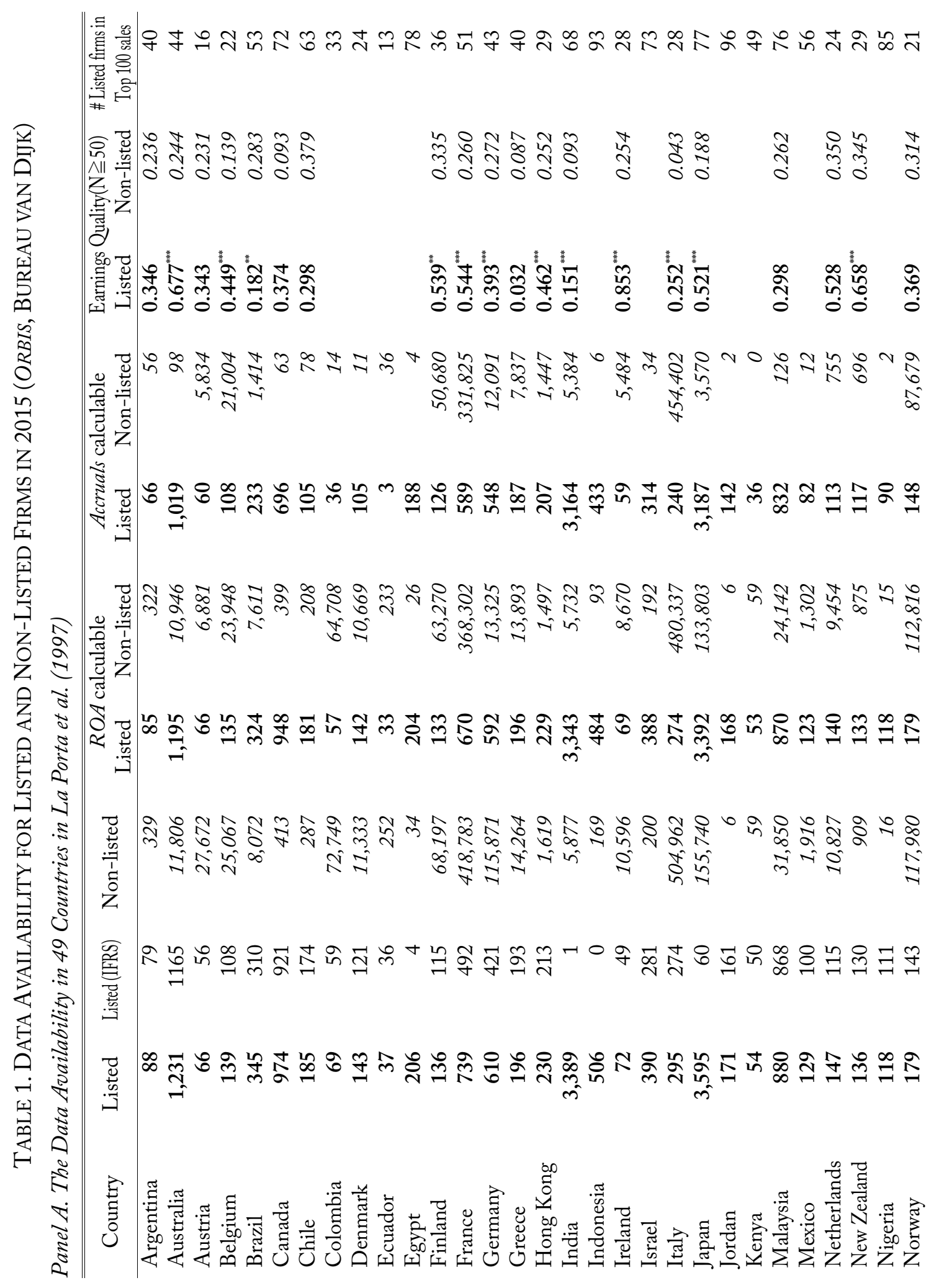




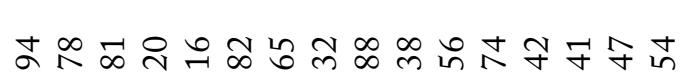

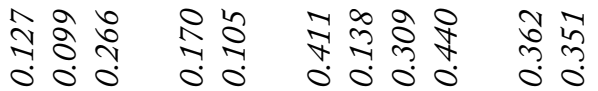

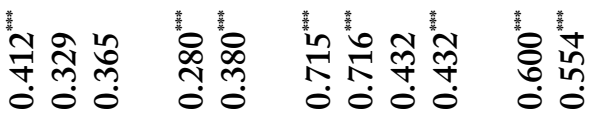

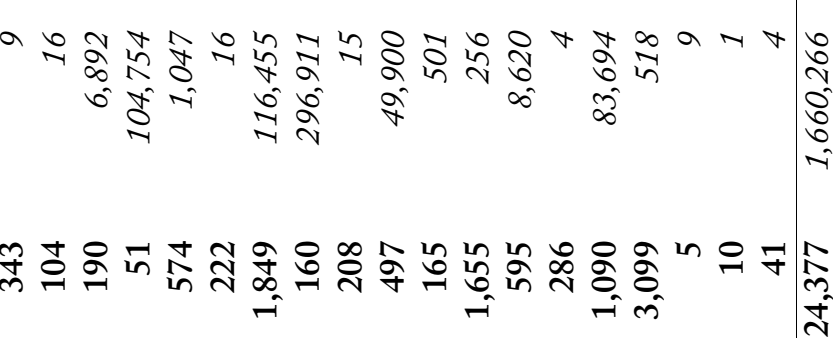

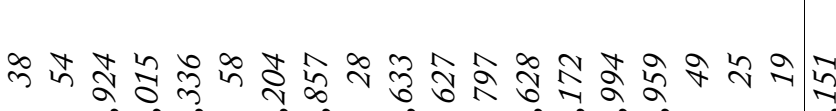

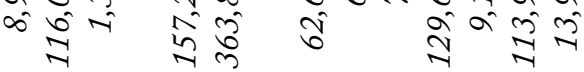

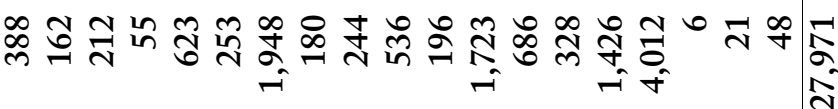

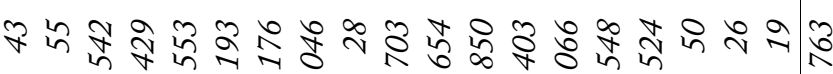

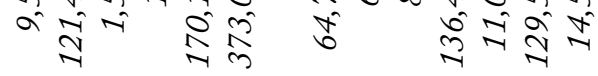

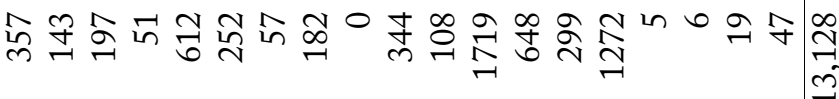

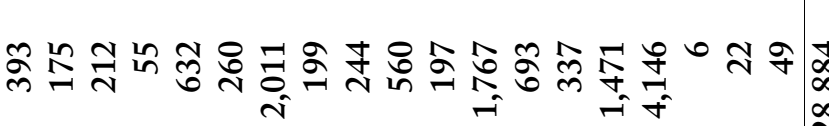

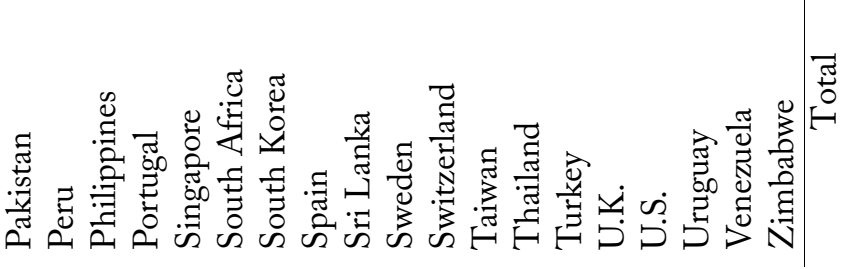

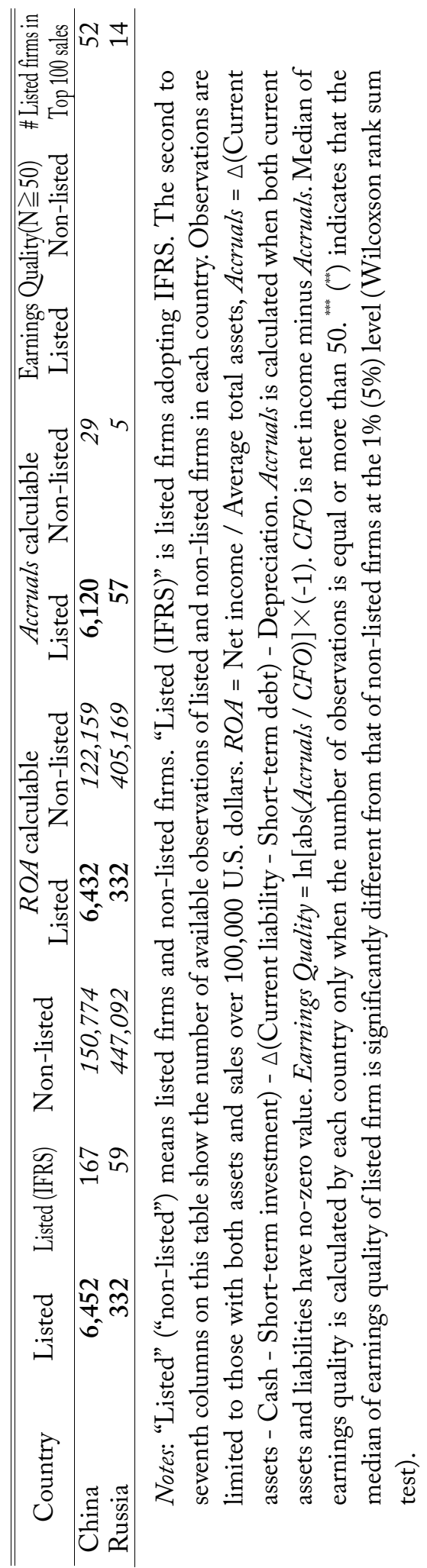


online in Sweden, whereas they are not available in the U.S. His table presents the greater availability in European countries compared to in the U.S., Canada, and Japan and this is consistent with Table 1 in this study. ${ }^{24}$

It is probable that the earnings quality of non-listed firms inherently differs from that of listed firms since non-listed firms are not subject to stock market regulations and external audits. Burgstahler et al. (2006) and Hope et al. (2013) present evidence that listed firms have better earnings quality than non-listed firms. The second and third columns of Table 1 show that listed firms' earnings quality is higher than that of non-listed firms, consistent with their research.

Van Tendeloo and Vanstraelen (2008) present evidence that in Europe, non-listed firms under Big-N audit have better earnings quality than under non-Big-N audits. However, the results are limited to countries with higher tax-book conformity. This is because tax authorities instead of security analysts, regulation authorities, and audit firms carry out high-quality scrutiny of financial statements in order to protect their reputation.

Previous research on non-listed firms often focuses on the lack of access to the public capital market unless the firms are scheduled to list. Financing of non-listed firms is not as diversified as listed firms, but firms still have various methods of financing such as borrowing (banking, leasing, government guarantee), stocks (family members, government, private equity), trade credit, and crowdfunding (Hope and Vyas 2017). As the type of accounting information of interest would vary with stakeholder, earnings quality may be affected by capital structure. For listed companies, financial statements are monitored by financial intermediaries such as investors and securities analysts whereas for non-listed firms the monitoring may be biased as it is only from debt holder and tax authorities.

It is likely that the relationship between the non-listed firm and fund provider depends on the institutional environment in the country. Peek et al. $(2010,55)$ state that for debt contracting and timely recognition of economic losses to be an effective solution to creditor-shareholder agency problems, contracts must be enforceable in court and creditors must have sufficient bargaining power in bankruptcy procedures. Gassen and Fulbier (2015) find that earnings smoothing is decreasing in countries with enhanced debt-contracting infrastructure such as the overall accessibility of credit financing, overall enforceability of contracts, and the effectiveness of mechanisms to resolve insolvency. I believe that the difference in this relationship in an international setting is an interesting question for future research. ${ }^{25}$

\subsection{Data Availability of International Database}

García Lara et al. (2006) state that data availability is one of the traditional obstacles in crosscountry research. They document that the difference in firm coverage among the databases leads to different results in empirical research. In addition to firm coverage, the following problems

${ }^{24}$ In Europe, the filing of financial statements with the relevant regulator is independent of the listing status, whereas in the U.S., for instance, private firms do not have to file with any easily available public registry (Hope and Vyas 2017, 507). As shown in Table 1, European countries, especially France, Italy, and Spain, tend to have relatively larger sample size than other countries.

25 As non-listed firms are characterized by ownership concentration and small size, the personality of its owner-manager could affect all aspects of management in the firm more than in listed firms. If so, earnings quality might be explained by cultural factors rather institutional factors relative to listed firms. Thus, I believe that the culture and earnings quality of non-listed firm is an interesting field for future research given the differential weight of cultural and institutional factors on earnings quality between listed and non-listed firms. 
TABLE 2. AVAILABILITY OF FINANCIAL STATEMENT ITEMS IN THE DATABASE

\begin{tabular}{lccc}
\hline \hline & $\begin{array}{c}\text { Balance } \\
\text { Sheet }\end{array}$ & $\begin{array}{c}\text { Income } \\
\text { Statement }\end{array}$ & $\begin{array}{c}\text { Cash-flow } \\
\text { statement }\end{array}$ \\
\hline $\begin{array}{l}\text { Orbis, Global Format } \\
\text { (listed and non-listed firms) }\end{array}$ & 22 & 16 & 1 \\
$\begin{array}{l}\text { Orbis, Detailed Format } \\
\text { (listed firms) }\end{array}$ & 89 & 29 & 28 \\
$\begin{array}{l}\text { Wrldscope } \\
\quad \text { (listed firms) }\end{array}$ & 83 & 33 & 38 \\
$\begin{array}{l}\text { Nikkei NEEDS FinancialQUEST } \\
\text { (firms filing annuai report to Cabinet }\end{array}$ & 241 & 90 & 102 \\
Office)
\end{tabular}

Notes: The number of footnote items is not included in this table. Nikkei NEEDS

FinancialQUEST counts the items for firms adopting Japanese accounting standards.

regarding databases are highlighted: the aggregation of financial statement items, and the lack of data other than financial statement items.

\section{(1) Firm coverage}

As shown in Table 1, not a few observations were omitted because of their size (e.g. assets below $\$ 100,000)$ and some observations did not contain important data such as assets and/or sales. Similary, the requirement for the calculation of Accruals reduces the sample size by around 15\% for listed firms and $40 \%$ for non-listed firms. In addition, the availability of non-listed firm data has a tendency to slant in countries mandatory filing of financial statements (as described in Section 4.3.). The mitigation of such a coverage problem would offer research opportunities.

\section{(2) Aggregation of financial statement items}

Databases for cross-country research usually aggregate financial statement items in order to use the common formats of the financial statement of firms around the world. Table 2 compares the available number of financial statement items in the database among three types of international database and one Japanese financial database. Orbis (Global format) is a common format for listed and non-listed firms, and Orbis (Detailed format) and Worldscope are for listed firms. Nikkei NEEDS FinancialQUEST (Nikkei Media Marketing) mainly consists of Japanese domestic firms that file a Yukashoken-Houkokusho (annual report) to Cabinet Office. ${ }^{26}$

In Table 2, we can observe that there is a difference in the available items for each database (not all the items contain non-missing data). ${ }^{27}$ The availability of the balance sheet and income statement items for the non-listed firm (Orbis, Global format) is only about 25\% to $50 \%$ compared to the number of items for the listed firms (Orbis, Detailed format and Worldscope). The number of balance sheet items in the Nikkei NEEDS FinancialQUEST is 2.7 (3.0) times as many items as in

${ }^{26}$ All of the listed firms in Japan are required to file Yukashoken-Houkokusho to the Cabinet Office within three months after the fiscal year end. Nikkei NEEDS FinancialQUEST also includes foreign firms listed in Japan.

27 I have accessed the three databases in Table 2 in September 2020 and counted the available items. 
Orbis detailed format (Worldscope). The number of income statement items in the Nikkei NEEDS FinancialQUEST is 3.1 (2.7) times as many items as in Orbis detailed format (Worldscope). Moreover, there are significantly more footnote items available in Nikkei NEEDS FinancialQUEST. The availability of detailed items allows researchers to conduct more detailed analysis.

(3) Data limitation of non-financial statement items

Even though the availability of financial statement data is expanding, there is still a limitation of data other than financial statement items (e.g. corporate governance, ownership, and board members) and contractual data (e.g. debt contract, and manager's compensation structure). It is difficult to obtain the sufficient types of data from the international database compared with the databases for individual country settings. The increase of data availability will lead to an extension of the analysis.

The future research described in 4.1 to 4.3 is closely related to the availability of data that researchers require. It cannot be stressed enough that the development of cross-country research depends on the extension of data availability.

\section{Conclusion}

The development of cross-country studies has provided evidence of what institutional factors affect earnings quality. This study reviewed the evidence and discusses future research.

Previous research illustrates country-level factors affecting earnings quality; the legal system such as investor protection, tax system, regulation, legal enforcement, political system, culture, religiosity, language, development of the securities market and financial institutions (financial development), industrial competitiveness, and accounting standards (distance from IAS or IFRS, IFRS adoption), and accounting standards enforcement. For future research, we can extend the individual country setting to a cross-country setting and investigate whether the evidence presented in the individual country setting is universal or whether it depends on the institutional and cultural factors at the country level.

IFRS has been adopted to enhance comparability through a single set of high-quality global accounting standards. Nevertheless, there is no unanimous evidence for the improvement of earnings quality after IFRS adoption. In particular, the results of mandatory IFRS adoption have been inconclusive. Furthermore, previous studies have revealed that institutional factors at the country-level (e.g. investor's protection and the enforcement of accounting standards) influence the improvement of earnings quality. The results suggest that the adoption of high-quality accounting standards alone is insufficient for improving earnings quality. It appears that institutional support is required to encourage managers to improve quality and the mechanism for controlling manager's incentive for earnings management.

In previous research, IFRS adoption has been shown to have positive effects on the capital market (Brüggemann et al. 2013). It can be interpreted that IFRS promote the decision-support role of accounting. However, with respect to the results on the effect on contracting roles, such as debt contracts, on accounting, the results are not unanimous. I believe that future research will explore the relationships between the change in earnings quality caused by IFRS adoption and the change in efficiency of various contracts in an international setting. In addition, this paper also provided the prospect for cross-country research on non-listed firms. Compared with research on listed firms, cross-country studies of non-listed firms are scarce. If the limitations of data permit it, 
a broader research area could be extended from the viewpoint of comparison between listed firms and non-listed firms.

\section{REFERENCES}

Aggarwal, R., L. Klapper, and P. Wysocki. 2005. Portfolio preferences of foreign institutional investors. Journal of Banking and Finance 29 (12): 2919-2946.

Ahmed, K., K. Chalmers, and H. Khlif. 2013a. A meta-analysis of IFRS adoption effects. The International Journal of Accounting 48 (2): 173-217.

Ahmed, A. S., M. Neel, and D. Wang. 2013b. Does mandatory adoption of IFRS improve accounting quality? Preliminary evidence. Contemporary Accounting Research 30 (4): 1344-1372.

André, P., A. Filip, and L. Paugam. 2015. The effect of mandatory IFRS adoption on conditional conservatism in Europe. Journal of Business Finance and Accounting 42 (3-4): 482-514.

Ashbaugh, H., and M. Pincus. 2001. Domestic accounting standards, International Accounting Standards, and the predictability of earnings. Journal of Accounting Research 39 (3): 417-34.

Aussenegg, W., P. Inwinkl, and G. Schneider. 2008. Earnings Management and Local vs. International Accounting Standards of European Public Firm. Available at SSRN: https://ssrn.com/abstract=1310346.

Ball, R., S. P. Kothari, and A. Robin. 2000. The effect of international institutional factors on properties of accounting earnings. Journal of Accounting and Economics 29 (1): 1-51.

Ball, R., A. Robin, and J. Wu. 2003. Incentives versus standards: properties of accounting income in four East Asia countries. Journal of Accounting and Economics 36 (1-3): 235-270.

Barth, M. E., W. R. Landsman, and M. H. Lang. 2008. International accounting standards and accounting quality. Journal of Accounting Research 46 (3): 467-498.

Beck, T., and R. Levine. 2002. Industry growth and capital allocation: Does having a market- or bank based system matter? Journal of Financial Economics 64 (2): 147-180.

Becker, C. L., M. L. DeFond, J. Jiambalvo and K. R. Subramanyam. 1998. The effect of audit quality on earnings management. Contemporary Accounting Research 15 (1): 1-24.

Beuselinck, C., B. Blanco, and J. M. García Lara. 2017. The role of foreign shareholders in disciplining financial reporting view. Journal of Business Finance and Accounting 44 (5-6): 558592.

Bonacchi, M., A. Marra, and P. Zarowin. 2019. Organizational structure and earnings quality of private and public firms. Review of Accounting Studies 24 (3): 1066-1113.

Bonetti, P., M. L. Magnan, and A. Parbonetti. 2016. The influence of country- and firm-level governance on financial reporting quality: Revisiting the evidence. Journal of Business, Finance and Accounting 43 (9-10): 1059-1094.

Boonlert-U-Thai, K., G. K. Meek, and S. Nabar. 2006. Earnings attributes and investor protection: International evidence. The International Journal of Accounting 41 (4): 327-357.

Braam, G., M. Nandy, U. Weitzel, and S. Lodh. 2015. Accrual-based and real earnings management and political connections. The International Journal of Accounting 50 (2): 111-141.

Brown, P., J. Preiato, and A. Tarca. 2014. Measuring country differences in enforcement of accounting standards: An audit and enforcement proxy. Journal of Business Finance and Accounting 41 (1-2): 1-52. 
Brüggemann, U., J. -M. Hitz, and T. Sellhorn. 2013. Intended and unintended consequences of mandatory IFRS adoption: A review of extant evidence and suggestions for future research. European Accounting Review 22 (1): 1-37.

Burgsthaler, D., L. Hail, and C. Leuz. 2006. The importance of reporting incentives: earnings management in European private and public firms. The Accounting Review 81 (5): 983-1016.

Bushman, R. M., and J. D. Piotroski. 2006. Financial reporting incentives for conservative accounting: The influence of legal and political institutions. Journal of Accounting and Economics 42 (1-2): 107-148.

Cai, L., A. Rahman, and S. Courtenay. 2014. The effect of IFRS adoption conditional upon the level of pre-adoption divergence. The International Journal of Accounting 49 (2): 147-178.

Callen, J., M. Morel., and G. Richardson. 2011. Do culture and religion mitigate earnings management? Evidence from a cross-country analysis. International Journal of Disclosure and Governance 8 (2): 103-121.

Capkun., V., D. Collins, and T. Jeanjean. 2016. The effect of IAS/IFRS adoption on earnings management (smoothing): A closer look at competing explanations. Journal of Accounting and Public Policy 35 (4): 352-394.

Chen, T., C. L. Chin, S. Wang, and C. Yao. 2015. The effects of financial reporting on bank loan contracting in global markets: Evidence from mandatory IFRS adoption. Journal of International Accounting Research 14 (2): 45-81.

Chen, C. J. P., Y. Ding, and Xu, B. 2011. Convergence of accounting standards and foreign direct investment. The International Journal of Accounting 49 (1): 53-86.

Chen, K. C. W., and F. Tang. 2017. Post-IFRS revaluation adjustments and executive compensation. Contemporary Accounting Research 34 (2): 1210-1231.

Chen, H., Q. Tang, Y. Jiang, and Z. Lin. 2010. The role of international financial reporting standards in accounting quality: Evidence from the European Union. Journal of International Financial Management and Accounting 21 (3): 220-278.

Christensen, H. B., L. Hail, and C. Leuz. 2013. Mandatory IFRS reporting and changes in enforcement. Journal of Accounting and Economics 56 (2-3): 147-177.

Christensen, H. B., E. Lee, M. Walker, and C. Zeng. 2015. Incentives or standards: What determines accounting quality changes around IFRS adoption? European Accounting Review 24 (1): 31-61.

Cohen, D. A., A. Dey, and T. Z. Lys. 2008. Real and accrual-based earnings management in the pre-and post-Sarbanes-Oxley periods. The Accounting Review 83 (3): 757-787.

Daske, H., L. Hail, C. Leuz, and R. Verdi. 2008. Mandatory IFRS reporting around the world: Early evidence on the economic consequences. Journal of Accounting Research 46 (5): 10851142.

Daske, H., L. Hail, C. Leuz, and R. Verdi. 2013. Adopting a label: Heterogeneity in the economic consequences around IAS/IFRS adoptions. Journal of Accounting Research 51 (3): 495-547.

De George, E.T., X. Li, and L. Shivakumar. 2016. A review of the IFRS adoption literature. Review of Accounting Studies 21 (3): 898-1004.

Dechow, P. M., and I. D. Dichev. 2002. The quality of accruals and earnings: The role of accrual estimation errors. The Accounting Review 77 (4): 35-59.

Dechow, P. M., W. Ge, and C. M. Schrand. 2010. Understanding earnings quality: A review of the proxies, their determinants and their consequences. Journal of Accounting and Economics 50 (23): 344-401. 
Degeorge, F., Y. Ding, T. Jeanjean, and H. Stolowy. 2013. Analyst coverage, earnings management and financial development: An international study. Journal of Accounting and Public Policy 32 (1): $1-25$.

Ding, Y., T. Jeanjean, and H. Stolowy. 2005. Why do national GAAP differ from IAS? The role of culture. The International Journal of Accounting 40 (4): 325-350.

Ding, Y., O.-K. Hope, T. Jeanjean, and H. Stolowy. 2007. Differences between domestic accounting standards and IAS: Measurement, determinants and implications. Journal of Accounting and Public Policy 26 (1): 1-38.

Djankov, S., R. La Porta, F. Lopezde-Silanes, and A. Shleifer. 2008. The law and economics of self-dealing. Journal of Financial Economics 88 (3): 430-465.

Dou, Y., O.-K. Hope, W. B. Thomas, and Y. Zou. 2016. Individual large shareholders, earnings management, and capital-market consequences. Journal of Business Finance and Accounting 43 (7-8): 872-902.

Doukakis, L. 2014. The effect of mandatory IFRS adoption on real and accrual-based earnings management activities. Journal of Accounting and Public Policy 33 (6): 551-572.

Doupnik, T. 2008. Influence of culture on earnings management. A note. Abacus 44 (3): 317-340.

Enomoto, M. 2018. Large-scale data and cross-country research. Kaikei 193 (1): 25-37. (in Japanese)

Enomoto, M., F. Kimura., and T. Yamaguchi. 2015. Accrual-based and real earnings management: An international comparison for investor protection. Journal of Contemporary Accounting and Economics 11 (3): 183-198.

Enomoto, M., F. Kimura, and T. Yamaguchi. 2018. A cross-country study on the relationship between financial development and earnings management. Journal of International Financial Management and Accounting 29 (2): 166-194.

Ewert, R., and A. Wagenhofer. 2005. Economic effects of tightening accounting standards to restrict earnings management. The Accounting Review 80 (4): 1101-1124.

Fonseca, A., and F. Gonzalez. 2008. Cross-country determinants of bank income smoothing by managing loan-loss provisions. Journal of Banking and Finance 32 (2): 217-228.

Francis, B., I. Hasan, and L. Li. 2016. A cross-country study of legal-system strength and real earnings management. Journal of Accounting and Public Policy 35 (5): 477-512.

Francis, J. R., E. L. Maydew, and H. C. Sparks. 1999. The role of big 6 auditors in the credible reporting of accruals. Auditing: A Journal of Practice and Theory 18 (2): 17-34.

Francis, J. R., and D. Wang. 2008. The joint effect of investor protection and Big 4 audits on earnings quality around the world. Contemporary Accounting Research 25 (1): 157-191.

Franks, J., C. Mayer, P. Volpin, and H. F. Wagner. 2012. The life cycle of family ownership: International evidence. The Review of Financial Studies 25 (6): 1675-1712.

García Lara, J. M., B. García Ozma, and B. G. de Albornoz Noguer. 2006. Effects of database choice on international accounting research. Abacus 42 (3-4): 426-454.

Gassen, J. 2017. The effect of IFRS for SMEs on the financial reporting environment of private firms: an exploratory interview study. Accounting and Business Research 47 (5): 540-563.

Gassen, J., and R. U. Fulbier. 2015. Do creditors prefer smooth earnings? Evidence from European private firms. Journal of International Accounting Research 14 (2): 151-180.

Gopalan, R., and S. Jayaraman. 2012. Private control benefits and earnings management: Evidence from insider controlled firms. Journal of Accounting Research 50 (1): 117-157. 
Gordon, E. A., G. Gotti, J. H. Ho, A. Mora, and R. D. Morris. 2019. Commentary: Where is international accounting research going? Issues needing further investigation. Journal of International Accounting, Auditing and Taxation 37: 100286.

Gordon, L. A., M. P. Loeb, and W. Zhu. 2014. The impact of IFRS adoption on foreign direct investment. Journal of Accounting and Public Policy 31 (4): 374-398.

Gray, S. J. 1988. Towards a theory of cultural influence on the development of accounting systems internationally. Abacus 24 (1): 1-15.

Griffin, D. W., O. Guedhami, C. C. Y. Kwok, K. Li, and L. Shao. 2017. National Culture and the Value Implication of Corporate Governance. Available at SSRN: https://ssrn.com/abstract=2400078.

Guan, L., H. Pourjalali, P. Sengupta, and J. Teruya. 2005. Effect of cultural environment and accounting regulation on earnings manipulation: A five Asian-Pacific country analysis. Multinational Business Review 13 (2): 1-20.

Han, S., T. Kang, S. Salter, and Y. K. Yoo. 2010. A cross-country study on the effects of national culture on earnings management. Journal of International Business Studies 41 (1): 123-141.

Haw, I-M., I., B. Hu, L. Hwang, and W. Wu. 2004. Ultimate ownership, income management, and legal and extra-legal institutions. Journal of Accounting Research 42 (2): 423-462.

Haw, I-M. G., S. Simon, M. Ho, Y. Li, and F. Zhang. 2015. Product market competition, legal institutions, and accounting conservatism. Journal of International Accounting Research 14 (2): $1-39$.

Healy, P. M., and J. M. Wahlen. 1999. A review of the earnings management literature and its implications for standard setting. Accounting Horizons 13 (4): 365-383.

Holthausen, R. W. 1990. Accounting method choice: opportunistic behavior, efficient contracting and information perspectives. Journal of Accounting and Economics 12 (1-3): 207-218.

Hofstede, G. 1980. Culture's Consequences: International Differences in Work Related Values. Beverly Hills, CA: Sage Publications.

Hofstede, G. 2001. Culture's Consequences: Comparing Values, Behaviors, Institutions, and Organizations across Nations. Thousand Oaks, CA: Sage Publications.

Hope, O.-K. 2003. Firm-level disclosures and the relative roles of culture and legal origin. Journal of International Financial Management and Accounting 14 (3): 218-248.

Hope, O.-K., W. B. Thomas, and D. Vyas. 2013. Financial reporting quality of U.S. private and public firms. The Accounting Review 88 (5): 1715-1742.

Hope, O.-K., W. B. Thomas, and D. Vyas. 2017. Stakeholder demand for accounting quality and economic usefulness of accounting in U.S. private firms. Journal of Accounting and Public Policy 36 (1): 1-13.

Hope, O.-K., and D. Vyas. 2017. Private company finance and financial reporting. Accounting and Business Research 47 (5): 506-537.

Houqe, M. N., R. M. Monem, M. Tareq, and T.van Zij1.2016. Secrecy and the impact of mandatory IFRS adoption on earnings quality in Europe. Pacific-Basin Finance Journal 40 (B): 476-490.

Houqe, M. N., T. van Ziji, K. Dunstan, and A. K. M. W. Karim. 2012. The effect of IFRS adoption and investor protection on earnings quality around the world. The International Journal of Accounting 47 (3): 333-355.

Hunt, A., S. E. Moyer, and T. Shevlin. 2000. Earnings Volatility, Earnings Management, and Equity Value. Working paper.

Ipino, E., and A. Parbonetti. 2017. Mandatory IFRS adoption: the trade-off between accrual and real-based earnings management. Accounting and Business Research 47 (1): 91-121. 
Isidro, H., D. (DJ) Nanda, and P. D. Wysocki. 2020. On the relation between financial reporting quality and country attributes: Research challenges and opportunities. The Accounting Review 95 (3): 279-314.

Kanagaretnam, K., C. Y. Lim, and G. J. Lobo. 2010. Auditor reputation and earnings management, International evidence from the banking industry. Journal of Banking and Finance 34 (10): 2318-2327.

Kanagaretnam, K., C. Y. Lim, and G. J. Lobo. 2011. Effects of national culture on earnings quality of banks. Journal of International Business Studies 42 (6): 853-874.

Kanagaretnam, K., C. Y. Lim, and G. J. Lobo. 2014. Effects of international institutional factors on earnings quality of banks. Journal of Banking and Finance 39: 87-106.

Kanagaretnam, K., G. J. Lobo, and C. Wang. 2015. Religiosity and earnings management: international evidence from the banking industry. Journal of Business Ethics 132 (2): 277-296.

Kim, J.-B., Y. Kim, and J. Zhou. 2017. Languages and earnings management. Journal of Accounting and Economics 63 (2-3): 288-306.

Kim, J.-B., X. Li, Y. Luo, and K. Wang. 2016. Institutional Distance and the Monitoring Effect of Foreign Investors. Working Paper.

Kim, J.-B., J. S. L. Tsui, and C. H. Yi. 2011. The voluntary adoption of International Financial Reporting Standards and loan contracting around the world. Review of Accounting Studies 16 (4): 779-811.

La Porta, R., F. Lopez-de-Silanes, A. Shleifer, and R. Vishny. 1997. Legal determinants of external finance. The Journal of Finance 52 (3): 1131-1150.

La Porta, R., F. Lopez-de-Silanes, A. Shleifer, and R. Vishny. 1998. Law and finance. Journal of Political Economy 106 (6): 1113-1155.

Lel, U. 2019. The role of foreign institutional investors in restraining earnings management activities across countries. Journal of International Business Studies 50 (6): 895-922.

Leuz, C., D. Nanda, and P. D. Wysocki. 2003. Earnings management and investor protection: An international comparison. Journal of Financial Economics 69 (3): 505-527.

Li, S. 2010. Does mandatory adoption of International Financial Reporting Standards in the European Union reduce the cost of equity capital? The Accounting Review 85 (2): 607-636.

Miyajima, M. 2017. Kigyo-Touchi Seido Kaikaku no 20 Nen. in Miyajima, M. eds Kigyo-Touchi to Kigyo-Senryaku. Toyo Keizai Inc. (In Japanese)

Obinata, T., 2016. Reexamination of La Porta et al. (1998). Journal of Business Administration 63 (3): 227-242. (in Japanese)

$\mathrm{O} z$, I., and T. Yelkenci. 2018. Examination of real and accrual earnings management: A crosscountry analysis of legal origin under IFRS. International Review of Financial Analysis. 58: 2437.

Ozkan, N., Z. Singer, and H. You. 2012. Mandatory IFRS adoption and the contractual usefulness of accounting information in executive compensation. Journal of Accounting Research 50 (4): 1077-1107.

Pacheco Paredes, A. A., and C. Wheatley. 2017. The influence of culture on real earnings management. International Journal of Emerging Markets 12 (1): 38-57.

Peek, E., R.J. R. Cuijpers, and W. F.J. Buijink. 2010. Creditors' and shareholders' reporting demands in public versus private firms: evidence from Europe. Contemporary Accounting Research 27 (1): 41-91. 
Roychowdhury, S. 2006. Earnings management through real activities manipulation. Journal of Accounting and Economics 42 (3): 335-370.

Salter, S. B., T. Kang, G. Gotti, and T. S. Doupnik. 2013. The role of social values, accounting values and institutions in determining accounting conservatism. Management International Review 53 (4): 607-632.

Shen, C., and H. Chih. 2005. Investor protection, prospect theory, and earnings management: An international comparison of the banking industry. Journal of Banking and Finance 29 (10): 2675-2697.

Spamann, H. 2010. The "antihdirector rights index" revisited. Review of Financial Studies 23 (2): 467-486.

Tax Justice Network. 2015. Financial Secrecy Index. Available at http://www.financialsecrecyindex.com. Tsang, A., F. Xie, and X. Xin. 2019. Foreign institutional investors and corporate voluntary disclosure around the world. The Accounting Review 94 (5): 319-348.

Van Tendeloo, B., and A. Vanstraelen. 2008. Earnings management and audit quality in Europe: Evidence from the private client segment market. European Accounting Review 17 (3): 447469.

Voulgaris, G., K. Stathopoulos, and M. Walker. 2014. IFRS and the use of accounting-based performance measures in executive pay. The International Journal of Accounting 49 (4): 479-514.

Yip, R. W., and D. Young. 2012. Does mandatory IFRS adoption improve information comparability? The Accounting Review 87 (5): 1767-1789.

Yung, K., and A. Root. 2019. Policy uncertainty and earnings management: International evidence. Journal of Business Research 100: 255-267.

Wijayana, S., and S. J. Gray. 2019. Institutional factors and earnings management in the AsiaPacific: Is IFRS adoption making a difference? Management International Review 59 (2): 307334.

World Economic Forum. 2012. The Financial Development Report 2012, Available at the World Economic Forum website: http://www.weforum.org/reports/financial-development-report2012.

Wysocki, P. 2011. New institutional accounting and IFRS. Accounting Business Research 41 (3): 309328.

Zeghal, D., S. M. Chtourou, and Y. M. Fourati. 2012. The effect of mandatory adoption of IFRS on earnings quality: Evidence from the European Union. Journal of International Accounting Research 11 (2): 1-25. 